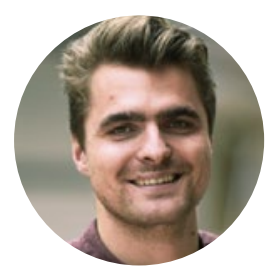

HUGO SCHALKWIJK

\title{
Vervang zeeheld door zorgheld
}

In de afgelopen maanden stond het leven van veel verpleegkundigen en verzorgenden in het teken van corona. De samenleving klapte, bedankte en bestempelde hen als zorghelden. Maar nu puntje bij paaltje komt, lijkt de waardering vergeten. De beloofde 'coronabonus' liet lang op zich wachten en de roep om structurele salarisverhogingen lijkt na drie stemrondes in de Tweede Kamer definitief aan dovenmansoren gericht.

\section{Cruciaal voor overlevingskansen}

De geschiedenis leert ons dat dit geen nieuw fenomeen is. Verpleegkundigen en verzorgenden zijn in elke pandemie van enorme waarde, maar krijgen zelden de eer die ze verdienen. Dat komt deels omdat hun werk niet goed gedocumenteerd wordt. Ten tijde van de Spaanse griep of de hiv/aidscrisis bijvoorbeeld, ziektes waar het (aanvankelijk) aan een effectieve behandeling ontbrak, was het verpleegkundig werk cruciaal voor de overlevingskansen van de patiënt. In de loop der jaren is de kennis over dit werk echter naar de achtergrond verdwenen.

Om de ervaringen van verpleegkundigen en verzorgenden tijdens de coronacrisis wél te bewaren, lanceerde FNI in april de COVID-19-verhalenbank op FNI.nl. Verpleegkundigen en verzorgenden kunnen laagdrempelig hun verhaal inzenden. Door het documenteren, organiseren en archiveren van hun ervaringen, blijft de rol die zij speelden bewaard en in het collectief geheugen geprent. Dit groeiende archief (inzenden is nog steeds mogelijk!) helpt toekomstige onderzoekers de rol van verpleegkundigen en verzorgenden goed te belichten en zo de discussie over maatschappelijke waardering op gang te houden.

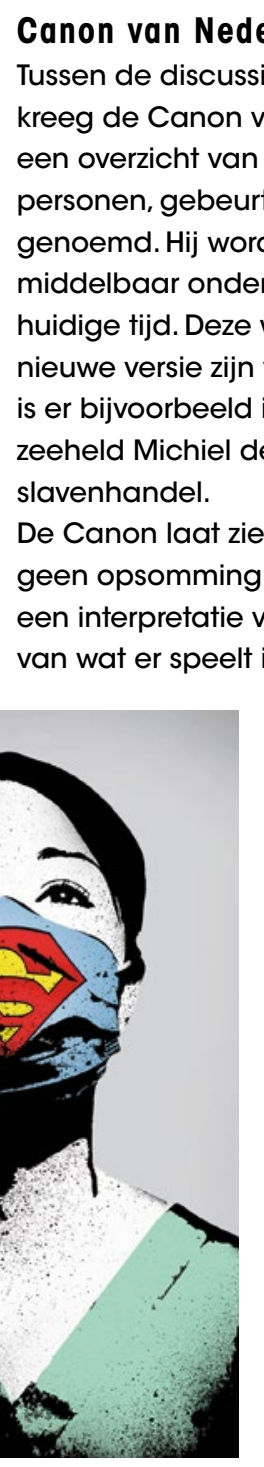

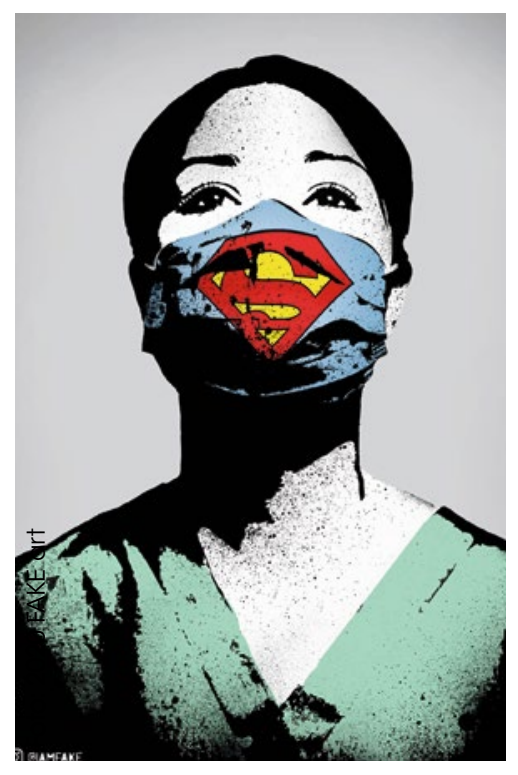
van deze tijden bewaard blijft. Het is dus belangrijk dat we hier nu al over nadenken.

De commissie die de herijking van de Canon vormgaf, beveelt aan dat deze regelmatig een verandering ondergaat. Voor de volgende verandering stel ik alvast het volgende voor: schrap de zeeheld, introduceer de zorgheld! Zo leren volgende generaties hoe onmisbaar verpleegkundigen en verzorgenden zijn. Dan kan niemand de roep om waardering nog negeren toch?

\section{REFERENTIES}

1. www.canonvannederland.nl/

2. www.nrc.nl/nieuws/2020/06/24/canon-

weerspiegelt-zowel-heden-als-verleden-a4003824

\section{'Verpleegkundigen en verzorgenden krijgen zelden de eer die ze verdienen'}

